\title{
NRF2-mediated signaling is a master regulator of transcription factors in bovine granulosa cells under oxidative stress condition
}

\author{
Mohamed Omar Taqi ${ }^{1,2} \cdot$ Mohammed Saeed-Zidane $^{1,3} \cdot$ Samuel Gebremedhn ${ }^{1,5}$. Dessie Salilew-Wondim ${ }^{1}$. \\ Ernst Tholen ${ }^{1} \cdot$ Christiane Neuhoff $^{1} \cdot$ Michael Hoelker $^{1,4} \cdot$ Karl Schellander $^{1} \cdot$ Dawit Tesfaye $^{1,5}$ (i)
}

Received: 23 March 2020 / Accepted: 1 March 2021 / Published online: 19 May 2021

(c) This is a U.S. government work and not under copyright protection in the U.S.; foreign copyright protection may apply 2021

\begin{abstract}
Transcription factors (TFs) are known to be involved in regulating the expression of several classes of genes during folliculogenesis. However, the regulatory role of TFs during oxidative stress (OS) is not fully understood. The current study was aimed to investigate the regulation of the TFs in bovine granulosa cells (bGCs) during exposure to OS induced by $\mathrm{H}_{2} \mathrm{O}_{2}$ in vitro. For this, bGCs derived from ovarian follicles were cultured in vitro till their confluency and then treated with $\mathrm{H}_{2} \mathrm{O}_{2}$ for $40 \mathrm{~min}$. Twenty-four hours later, cells were subjected to various phenotypic and gene expression analyses for genes related to TFs, endoplasmic reticulum stress, apoptosis, cell proliferation, and differentiation markers. The bGCs exhibited higher reactive oxygen species accumulation, DNA fragmentation, and endoplasmic reticulum stress accompanied by reduction of mitochondrial activity after exposure to OS. In addition, higher lipid accumulation and lower cell proliferation were noticed in $\mathrm{H}_{2} \mathrm{O}_{2}$-challenged cells. The mRNA level of TFs including NRF2, E2F1, KLF6, KLF9, FOS, SREBF1, SREBF2, and $\mathrm{NOTCHI}$ was increased in $\mathrm{H}_{2} \mathrm{O}_{2}$-treated cells compared with non-treated controls. However, the expression level of $K L F 4$ and its downstream gene, $C C N B 1$, were downregulated in the $\mathrm{H}_{2} \mathrm{O}_{2}$-challenged group. Moreover, targeted inhibition of $N R F 2$ using small interference RNA resulted in reduced expression of KLF9, FOS, SREBF2, and NOTCH1 genes, while the expression of KLF4 was upregulated. Taken together, bovine granulosa cells exposed to OS exhibited differential expression of various transcription factors, which are mediated by the NRF2 signaling pathway.
\end{abstract}

Keywords Transcription factors · Granulosa cells $\cdot$ Oxidative stress $\cdot$ Apoptosis and differentiation $\cdot$ NRF2 signaling

\section{Introduction}

In the mammalian follicle, the oocyte is surrounded by multiple layers of somatic cells including granulosa cells, which play a significant role during oocyte maturation by

Dawit Tesfaye

Dawit.Tesfaye@colostate.edu

1 Institute of Animal Science, Animal Breeding and Husbandry Group, University of Bonn, Bonn, Germany

2 Central Laboratory for Agricultural Climate, Agricultural Research Center, Giza, Egypt

3 Institute of Animal Breeding and Husbandry, Animal Breeding and Genetics Group, University of Kiel, Kiel, Germany

4 Teaching and Research Station Frankenforst, University of Bonn, Koenigswinter, Germany

5 Department of Biomedical Sciences, Animal Reproduction and Biotechnology Laboratory (ARBL), Colorado State University, Fort Collins, CO, USA producing paracrine factors including estradiol and progesterone (Wen et al. 2010). Thus, disruption of granulosa cell functions may result in poor oocyte quality and subsequently reduction in pregnancy rate (Lai et al. 2018). Previous studies have evidenced that exposure of granulosa cells to oxidative stress has led to impaired function and subsequently poor quantity and quality of oocytes (Jancar et al. 2007; Lai et al. 2018; Rajani et al. 2012). Despite the fact that accumulation of reactive oxygen species (ROS)-induced oxidative stress harms granulosa cell function, elevated levels of ROS at the time of ovulation play an indispensable role in facilitating the ovulation process (Tanabe et al. 2015).

ROS are endogenously produced during metabolic pathways as a byproduct from different cellular compartments including the plasma membrane, mitochondria, endoplasmic reticulum, and peroxisomes (Di Meo et al. 2016). Cells are equipped with a well-balanced system including antioxidant machinery to eliminate the excessive levels of ROS and maintain cellular redox homeostasis (He et al. 2017). 
However, disruption of this balanced system due to overwhelmed cellular ROS production leads to oxidative stress (Agarwal et al. 2006). Excessive ROS accumulation and subsequent oxidative stress could also arise from external and/or internal stressors such as heat stress (Alemu et al. 2018), inflammation (Mittal et al. 2014), and endoplasmic reticulum stress (Liu et al. 2018). Exposure of cells to oxidative stress has a negative impact on cell membrane permeability and mitochondrial activity and causes DNA damage (Kadenbach et al. 2004; Zhang et al. 2016) resulting in cell cycle arrest (Saeed-Zidane et al. 2017) and apoptosis (Sohel et al. 2019).

Mammalian cells respond to intra and extracellular signals by altering several transcription factors (TFs) that activate and/or inhibit genes involved in various biological functions (Leite et al. 2017). Some of those TFs are believed to be involved in cellular defense mechanisms against oxidative stress (Mikaeili et al. 2016; Weng et al. 2016). In bovine embryos, the capability of in vitro produced embryos to survive under oxidative stress conditions relies on the activation of nuclear factor (erythroid-derived 2)-like 2 (NRF2 or NFE2L2) transcription factor at mRNA and protein levels (Amin et al. 2014). Similarly, NRF2 is responsible for the activation of cellular antioxidant machinery in bovine granulosa cells under oxidative stress conditions (Alemu et al. 2018; Khadrawy et al. 2019; Sohel et al. 2019, 2018). Moreover, $N R F 2$ could be extracellularly released via exosomes and horizontally transferred to neighboring cells as a means of inducing adaptive response against oxidative stress in recipient cells (Saeed-Zidane et al. 2017).

NRF2 might particularly be involved in the regulation of other TF networks such as NOTCH (Zhao et al. 2016), Krüppel-like factor $(K L F s)$ family members (Jang et al. 2014; Zucker et al. 2014), and sterol regulatory elementbinding transcription factor (SREBFs) family (Amin et al. 2014; Kamisako et al. 2014), which are involved in cell proliferation, differentiation, apoptosis (Andersson et al. 2011; Miao et al. 2017), fatty acids, and cholesterol biosynthesis (Daemen et al. 2013; Shimano 2001). Some of those TFs significantly contribute to the regulation of ovarian functions (Murta et al. 2015; Natesampillai et al. 2008) such as regulation of genes involved in steroidogenesis (Liu et al. 2009). Furthermore, the overexpression of the KLF family showed a negative effect on the expression of CYP11A1 in granulosa cells (Natesampillai et al. 2008). However, increasing intracellular ROS accumulation accompanied by overexpression of $N R F 2$ resulted in promoting cell death via regulation of KLF9 (Zucker et al. 2014). Moreover, apoptosis of granulosa cells could be induced via regulation of FOS after exposure to mycotoxin (Guerrero-Netro et al. 2015), which is one of the activator protein-1 (AP-1) members (Dias et al. 2013). However, little is known regarding the regulation of granulosa cell functions via various TFs under oxidative stress conditions and their relevance with the NRF2 signaling pathway. Therefore, the current study aimed to investigate the expression patterns of stress-induced TFs and their potential regulation by the $N R F 2$ signaling pathway in bovine granulosa cells exposed to oxidative stress.

\section{Materials and methods}

\section{Experimental setup}

To investigate the effect of $\mathrm{H}_{2} \mathrm{O}_{2}$ on the expression of the stress-related TFs and their association with the NRF2 signaling pathway in bovine granulosa cells, two independent experiments were conducted. In the first experiment, subconfluent bovine granulosa cells were treated with $5 \mu \mathrm{M}$ $\mathrm{H}_{2} \mathrm{O}_{2}$ for 40 min as optimized previously (Saeed-Zidane et al. 2017) to induce moderate oxidative stress. Moreover, based on previous pieces of evidence and in silico analysis, the second experiment was conducted to figure out the cross-talk between NRF 2 and other candidate TFs. For that, sub-confluent bovine granulosa cells were transfected with $200 \mathrm{nM}$ small interference RNA (siRNA) targeting NRF2. In both experiments, the cells were incubated at $37{ }^{\circ} \mathrm{C}$ in $5 \%$ $\mathrm{CO}_{2}$ for another $24 \mathrm{~h}$ after the treatment and then subjected to various phenotypic and genotypic analyses.

\section{In vitro culture of bovine granulosa cells}

Bovine ovaries were obtained from a local abattoir and transported in warm $\left(37^{\circ} \mathrm{C}\right)$ physiological saline $(0.9 \% \mathrm{NaCl})$ solution. Upon arrival, ovaries were washed three times with warm $\left(37^{\circ} \mathrm{C}\right) 0.9 \% \mathrm{NaCl}$, followed by prewarmed $\left(37^{\circ} \mathrm{C}\right) 70 \%$ ethanol washing. Granulosa cells were aspirated from small follicles $(3-5 \mathrm{~mm})$ in $15-\mathrm{mL}$ tubes containing prewarmed $\left(37{ }^{\circ} \mathrm{C}\right)$ phosphate-buffered saline, calcium- and magnesium-free (PBS-CMF) and then kept standing for $15 \mathrm{~min}$ at $37^{\circ} \mathrm{C}$ to let the cellular debris settled down at the bottom. Subsequently, the supernatants containing the granulosa cells were collected and centrifuged at $750 \mathrm{~g}$ for $7 \mathrm{~min}$ to get granulosa cell pellets. Afterwards, the cell viability and concentration were checked under the microscope using trypan blue staining. Ultimately, a total of $2.5 \times 10^{5}$ cells per well was cultured in CytoOne ${ }^{\circledR} 24$-well plate (Starlab GmbH, Hamburg, Germany) containing 600$\mu \mathrm{L}$ DMEM/F-12 medium (Sigma-Aldrich Chemie GmbH, Taufkirchen, Germany) supplemented with $10 \%$ fetal bovine serum (FBS) (Gibco ${ }^{\circledR}$, Karlsruhe, Germany) and 1\% penicillin/streptomycin and incubated at $37{ }^{\circ} \mathrm{C}$ in $5 \% \mathrm{CO}_{2}$. 


\section{Small interference RNA transfection}

Briefly, sub-confluent granulosa cells were transfected with 200 nM siRNA targeting NRF2 (siRNA-NRF2) or scrambled siRNA as a negative control (siRNA-ve) (Exiqon, Vedbaek, Denmark) in the presence of Lipofectamine ${ }^{\circledR}$ 2000 (Invitrogen, Carlsbad, California, USA) as transfection reagent diluted in Opti-MEM I reduced-serum medium (Invitrogen, Carlsbad, California, USA). Afterwards, cells were incubated for $24 \mathrm{~h}$ in a humidified $5 \% \mathrm{CO}_{2}$ incubator at $37^{\circ} \mathrm{C}$. Thereafter, cells were harvested and used for further analyses.

\section{Cell proliferation assay}

A total of $1.5 \times 10^{4}$ cells were cultured in 96 -well plates using the same procedure described above. Cells from both experiments were used for proliferation assay using CCK-8 kits (Dojindo EU GmbH, München, Germany) after 24 h post-treatment either with $\mathrm{H}_{2} \mathrm{O}_{2}$ or siRNA according to the manufacturer's protocol. The proliferation rate was indicated by the absorbance at $450 \mathrm{~nm}$ wavelength using Synergy ${ }^{\mathrm{TM}}$ H1 Multi-Mode Reader (BioTek Germany, Bad Friedrichshall, Germany).

\section{Intracellular ROS detection}

Granulosa cells were cultured in a 96-well plate and then the sub-confluent cells were treated with $\mathrm{H}_{2} \mathrm{O}_{2}$. After $24 \mathrm{~h}$, cells were co-incubated with FBS-free medium containing $75 \mu \mathrm{M}$ 2', 7'-dichlorodihydrofluorescein diacetate (H2DCFDA) (Invitrogen, Carlsbad, California, USA) for $20 \mathrm{~min}$ at $37^{\circ} \mathrm{C}$ in $5 \% \mathrm{CO}_{2}$. Subsequently, the cells were washed twice with PBS-CMF, and then, the images were captured using a green-fluorescence filter of the inverted fluorescence microscope (Leica DM IRB, Leica, Wetzlar, Germany). The fluorescence intensity was quantified using ImageJ $1.48 \mathrm{v}$ software (National Institutes of Health, Maryland, USA, http:// imagej.nih.gov).

\section{Mitochondrial activity assay}

To assess the cellular mitochondrial activity, a total of $4 \times 10^{4}$ live granulosa cells were seeded into 8-well slide chamber according to the manufacturer's protocol. Briefly, the granulosa cells were co-incubated with $200 \mathrm{nM}$ MitoTracker red dye (MitoTracker® Red CMXRos, M7512; Invitrogen) for $30 \mathrm{~min}$ in a $\mathrm{CO}_{2}$ incubator. Then, the cells were rinsed twice with PBS-CMF and subsequently fixed with $4 \%$ paraformaldehyde overnight at $4{ }^{\circ} \mathrm{C}$. Fixed cells were mounted with a Vectashield mounting medium containing DAPI. Finally, the images were acquired using confocal microscopy CLSM LSM-780 and the fluorescent intensity was analyzed with ImageJ $1.48 \mathrm{v}$ software (National Institutes of Health, Maryland, USA, http://imagej.nih.gov).

\section{Lipid accumulation assay}

Cells were cultured in a 96-well plate and treated with either $\mathrm{H}_{2} \mathrm{O}_{2}$ or siRNA. Twenty-four hours post-treatment, plates containing granulosa cells were gently rinsed with $50 \mu \mathrm{L}$ of PBS-CMF. Subsequently, cells were fixed using $4 \%$ paraformaldehyde overnight at $4{ }^{\circ} \mathrm{C}$ and then subjected to lipid accumulation assay. Briefly, a working solution was prepared by mixing three parts $(30 \mathrm{~mL})$ of oil red O (SigmaAldrich Chemie GmbH, Munich, Germany) from stock solution with 2 parts $(20 \mathrm{~mL})$ deionized water and then stored at room temperature for $10 \mathrm{~min}$ followed by filtration via filter paper. After removing the $4 \%$ paraformaldehyde, each well was gently rinsed by sterile water followed by co-incubation with $50 \mu \mathrm{L}$ of $60 \%$ isopropanol at room temperature for $5 \mathrm{~min}$. Afterwards, the isopropanol was poured off and 100$\mu \mathrm{L}$ working solution of oil red $\mathrm{O}$ was pipetted to each well and left for $5 \mathrm{~min}$. Following this, cells were rinsed with tap water and the images were captured using an inverted microscope with $40 \times$ magnification.

\section{DNA fragmentation assay}

The fragmented DNA was isolated according to the Abcam protocol (Cambridge, UK). Briefly, the floated and adhered cells were collected and then lysed in $500 \mu \mathrm{L}$ of $10 \mathrm{mM}$ Tris (pH 7.4), 5 mM EDTA, $0.2 \%$ Triton-X100 followed by vortexing for several times. The lysate was incubated on ice for $30 \mathrm{~min}$ followed by centrifugation at $27,000 \mathrm{~g}$ for $30 \mathrm{~min}$. Subsequently, the supernatants were divided into two parts and $50-\mu \mathrm{L}$ ice-cold $5 \mathrm{M} \mathrm{NaCl}$ was added to each part coupled with several times vortexing. Subsequently, a mixture containing $600 \mu \mathrm{L}$ ethanol and $150-\mu \mathrm{L} 3 \mathrm{M}$ sodium acetate (pH 5.2) was added to each aliquot with gentle mixing by pipetting and then incubated at $-80{ }^{\circ} \mathrm{C}$ for $1 \mathrm{~h}$ followed by centrifugation for $20 \mathrm{~min}$ at $20,000 \mathrm{~g}$. After discarding the supernatant, the pellets were pooled together and redissolved in $10 \mathrm{mM}$ Tris and $5 \mathrm{mM}$ EDTA accompanied by adding DNase-free RNase $10 \mathrm{mg} / \mathrm{mL}$ and then incubated in a water bath at $37^{\circ} \mathrm{C}$ for $5 \mathrm{~h}$. Afterwards, a combination of $25 \mu \mathrm{L}$ proteinase $\mathrm{K}$ at $20 \mathrm{mg} / \mathrm{mL}$ (Qiagen $\mathrm{GmbH}$, Hilden, Germany) and $40 \mu \mathrm{L}$ buffer (100 mM Tris pH 8.0, $100 \mathrm{mM}$ EDTA, and $250 \mathrm{mM} \mathrm{NaCl}$ ) was added and subsequently incubated overnight at $65{ }^{\circ} \mathrm{C}$. Thereafter, the DNA was extracted using phenol/chloroform/isoamyl alcohol mixture 
(25:24:1) (Biomol GmbH, Hamburg, Germany) and then precipitated using ethanol. The supernatant was carefully removed followed by air drying. The pellets were resuspended in 15- $\mu \mathrm{L} 1 \times$ TE buffer (Carl Roth GmbH, Karlsruhe, Germany). Finally, the samples were electrophoretically separated using a $2 \%$ agarose gel containing ethidium bromide and then visualized using ChemiDoc ${ }^{\mathrm{TM}} \mathrm{XRS}+$ system (Bio-Rad Laboratories GmbH, Germany).

\section{RNA isolation and CDNA synthesis}

Total RNA from granulosa cells was extracted using the miRNeasy ${ }^{\circledR}$ mini kit (Qiagen GmbH, Hilden, Germany) following the manufacturer's protocol. Before starting the total RNA extraction, granulosa cells were washed using $1 \times$ PBS to remove the remaining culture medium. At the end of the extraction protocol, trapped RNAs in the membrane of spin column were eluted using $30 \mu \mathrm{L}$ RNase-free water. RNA concentration was assessed using NanoDrop 8000 UV-Vis Spectrophotometers (Thermo Scientific, Wilmington, USA). Equal amounts of total RNA were reverse transcribed using the RevertAid first-strand cDNA synthesis kit (Thermo Fisher Scientific, Schwerte, Germany). Briefly, a combination from oligo-dT and random primer was added to each sample followed by incubation at $65^{\circ} \mathrm{C}$ for $5 \mathrm{~min}$. After incubation time, a mixture containing $1 \mu \mathrm{L}$ of RiboLock RNase inhibitor, $2 \mu \mathrm{L}$ of $10 \mathrm{mM}$ dNTP mix, $4 \mu \mathrm{L}$ of $5 \times$ reaction buffer, and $2 \mu \mathrm{L}$ of MMuLV reverse transcripts was added to each sample. Afterwards, samples were incubated at $25^{\circ} \mathrm{C}$ for $5 \mathrm{~min}$, then $37^{\circ} \mathrm{C}$ for $60 \mathrm{~min}$ followed by $70{ }^{\circ} \mathrm{C}$ for $5 \mathrm{~min}$ to terminate the reaction. Ultimately, the cDNA was kept at $-20{ }^{\circ} \mathrm{C}$ for further analysis.

\section{Real-time quantitative PCR}

The expression levels of candidate TFs (NRF2, NOTCH1, SREBF1, SREBF2, KLF4, KLF9, FOS, FOSB, IRF7, E2F1, and $E 2 F 4$ ), the $K L F 4$ downstream target genes (CCNB1, $C C N D 2$, and $B A X$ ), endoplasmic reticulum stress marker (Grp78, Grp94, and Calpain1), cell differentiation markers (CYP11A1, CYP19A1, STAR, INHBa, EGFR, and FOXO1), and apoptosis-related genes (BCL2L1 and CASP3) were quantified using iTaq ${ }^{\mathrm{TM}}$ Universal SYBR ${ }^{\circledR}$ Green Supermix (Bio-Rad Laboratories GmbH, München, Germany) in Applied Biosystem ${ }^{\circledR}$ StepOnePlus ${ }^{\mathrm{TM}}$ (Applied biosystems, Foster City, CA, USA). The primers were designed using the primer3 online tool (http://bioinfo.ut.ee/primer3-0.4.0/) (Supplementary Table 1). Subsequently, the specificity of the primers was confirmed by sequencing using the Genom$\mathrm{eLab}^{\mathrm{TM}}$ GeXP Genetic Analysis System (Beckman Coulter GmbH, Krefeld, Germany). The mRNA expression data were analyzed using comparative $\mathrm{Ct}\left(2^{-\Delta \Delta \mathrm{Ct}}\right)$ methods (Livak and Schmittgen 2001) and the geometric mean of the expression level of $A C T B$ and GAPDH was used for normalization after checking the expression stability with NormFinder software (Andersen et al. 2004).

\section{Immunoblotting}

Total protein from granulosa cells was isolated using $1 \times$ passive lysis buffer (Promega $\mathrm{GmbH}$, Mannheim, Germany) and the concentration was determined using Coomassie Protein Assay Reagent (Life Technologies GmbH, Darmstadt, Germany). Thirty-five micrograms of protein was loaded onto $12 \%$ SDS-polyacrylamide gel. After electrophoresis, proteins were transferred onto a nitrocellulose membrane (Bio-Rad Laboratories $\mathrm{GmbH}$, Germany) using Trans-Blot ${ }^{\circledR}$ SD Semi-Dry Transfer Cell (Bio-Rad Laboratories GmbH, Germany). Thereafter, the membrane was blocked in Roti®-Block (Carl Roth GmbH, Germany) for $1 \mathrm{~h}$ at room temperature. The membrane was incubated overnight at $4{ }^{\circ} \mathrm{C}$ with polyclonal primary antibodies specific for KLF4 (1:100), Grp78 (1:300), PRKAA 1/2 (1:350), StAR (1:250), and ACTB (1:500) mouse monoclonal antibody (Santa Cruz Biotechnology Inc, Germany). After the incubation with the primary antibody, the membrane was incubated with goat anti-rabbit or goat antimouse (1:5000; Santa Cruz Biotechnology Inc, Germany) secondary antibody with the respective candidate primary antibody for $1 \mathrm{~h}$ at room temperature. The proteins were visualized using Clarity ${ }^{\mathrm{TM}}$ Western ECL Substrate (BioRad Laboratories Inc, USA). The images were captured using the ChemiDoc ${ }^{\mathrm{TM}}$ XRS+ system (Bio-Rad Laboratories $\mathrm{GmbH}$, Germany). Subsequently, the membrane was stripped using a middle stripping buffer in order to remove primary and secondary antibodies followed by blocking and incubation with another antibody using the same protocol. As shown in supplementary Fig. 3, in both control and $\mathrm{H}_{2} \mathrm{O}_{2}$-treated cells, the StAR protein was detected at $30 \mathrm{kDa}$.

\section{Immunocytochemistry}

Localization and subsequent quantification of NRF2 and KLF4 proteins were conducted using the immunocytochemistry technique. For this, granulosa cells were seeded into 8-well slide chamber and subsequently treated with either $\mathrm{H}_{2} \mathrm{O}_{2}$ or siRNA. Twenty-four hours post-treatment, granulosa cells were fixed using $4 \%$ paraformaldehyde and kept at $4{ }^{\circ} \mathrm{C}$ overnight. Subsequently, the cells were rinsed three times with PBS-CMF and then incubated with $0.3 \%$ Triton X-100 (Roche Diagnostics 

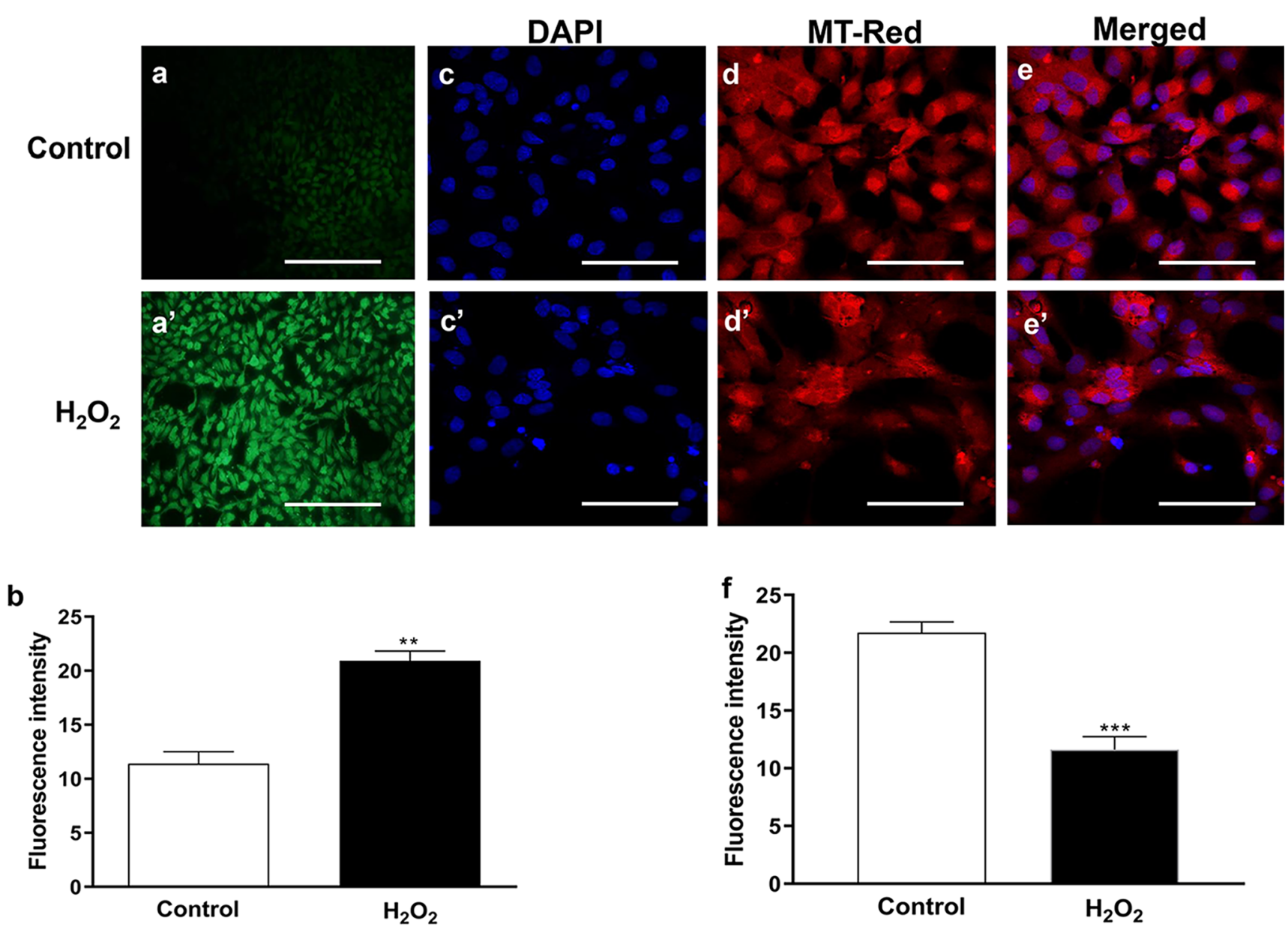

\section{g}
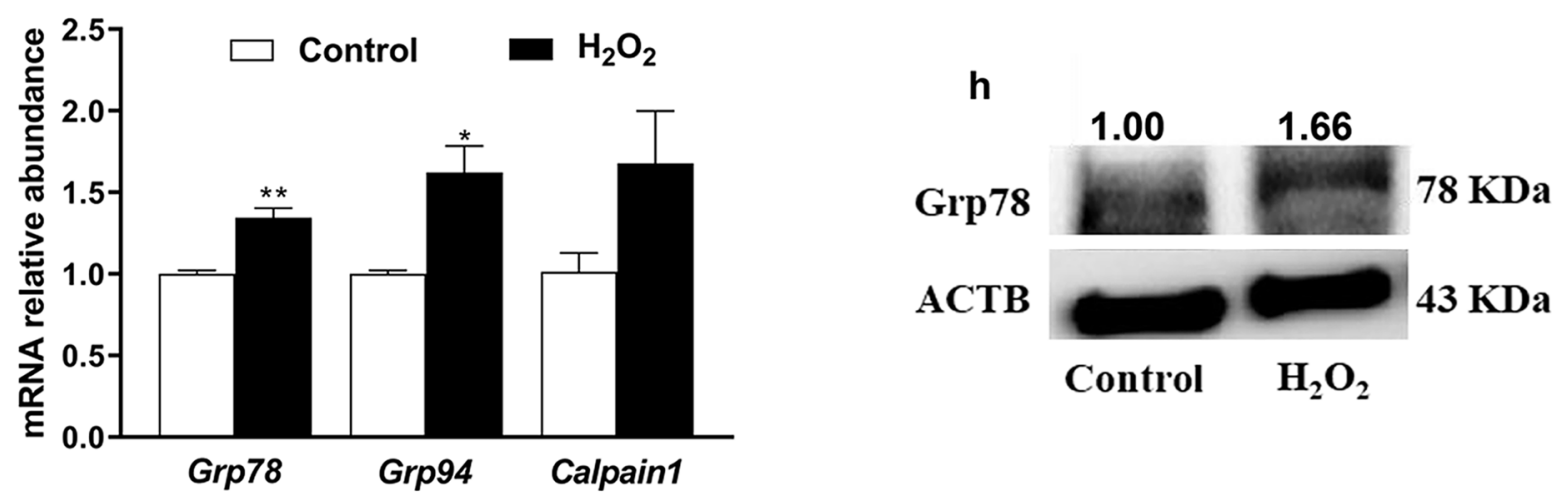

Fig. 1 Intracellular reactive oxygen species (ROS) accumulation a, b, mitochondrial activity c-f, the relative mRNA expression profile of endoplasmic reticulum stress marker genes $\mathbf{g}$, and protein level of Grp78 f of bovine granulosa cells under oxidative stress conditions. Green color a, a' indicates the fluorescence of the $2^{\prime}, 7^{\prime}$-dichlorodihydrofluorescein diacetate (H2DCFDA). The blue color c, c' indicates the nuclear staining using 40,6-diamidino-2-phenylindole (DAPI) and the red color $\mathbf{d}, \mathbf{d}$ ' indicates mitochondrial activity. The fluorescence and band intensity were measured by ImageJ software. Data were statistically analyzed with Student's two-tailed $t$ test and are shown as means \pm SEM of three independent replicates with different pools of cells $\left({ }^{*} p \leq 0.05, * * p \leq 0.01, * * * p \leq 0.001\right)$. Scale bars: $100 \mu \mathrm{m} \mathrm{a}, \mathbf{a}$, $20 \mu \mathrm{m}$ c-e' 
$\mathrm{GmbH}$, Mannheim, Germany) for 10 min followed by blocking with 3\% donkey serum (Sigma-Aldrich Chemie $\mathrm{GmbH}$, Munich, Germany) for $1 \mathrm{~h}$ at room temperature. Then, the cells were co-incubated with the primary antibody for NRF2 (1:100) or KLF4 (1:100) at $4{ }^{\circ} \mathrm{C}$ overnight. Thereafter, the cells were washed three times with PBS-CMF followed by co-incubation with fluorescent secondary antibody (Lifespan Biosciences, Alexa Fluor goat anti-rabbit $1: 350$ ) for $3 \mathrm{~h}$ at $37{ }^{\circ} \mathrm{C}$ in dark. Thereafter, the cells were washed three times with PBS-CMF and subsequently mounted with Vectashield mounting medium containing DAPI. Finally, the cells were visualized under confocal microscopy CLSM LSM-780 and the fluorescence intensity of proteins was analyzed using ImageJ $1.48 \mathrm{v}$ software (National Institutes of Health, Maryland, USA, http://imagej.nih.gov).

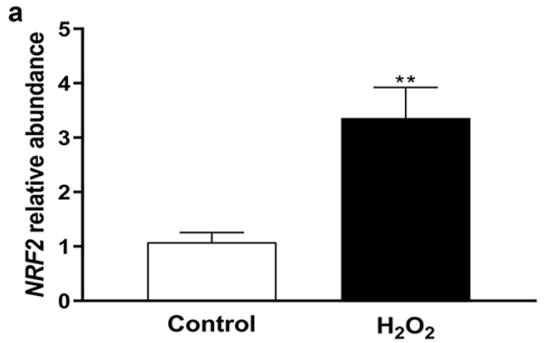

f
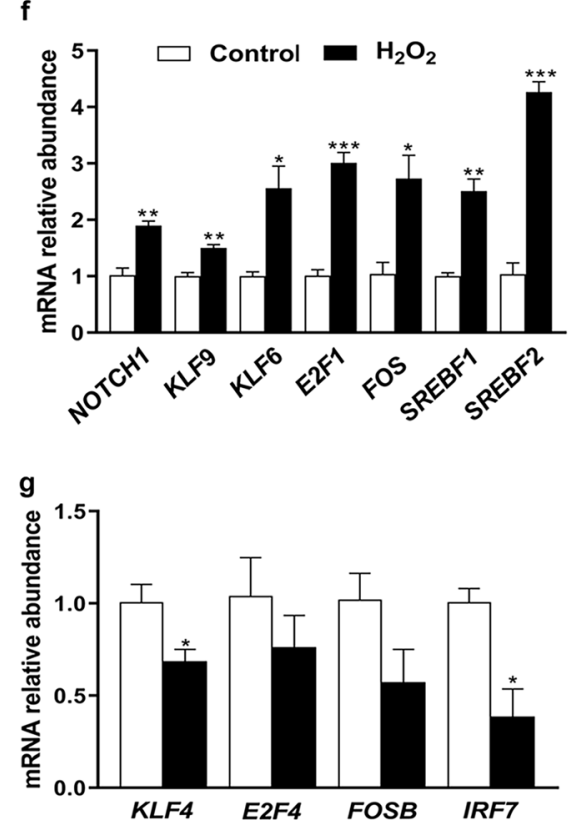

Fig. 2 Relative abundance of the transcription factors in bovine granulosa cells exposed to oxidative stress. The expression pattern of $N R F 2$ mRNA a and its protein b-e in response to oxidative stress, whereby the blue color $\mathbf{b}$, b' indicates the nuclear staining using 40,6-diamidino-2-phenylindole (DAPI) and the red color c, c' indicates the NRF2 protein; the effect of oxidative stress on candidate transcription factors, which showed up $\mathbf{f}$ and downregulation

\section{Statistical analysis}

Data were represented as means \pm SEM from at least three independent replicates with different pools of cells. Data were statistically analyzed with Student's two-tailed $t$ test using GraphPad Prism software version 7 (GraphPad Software, La Jolla, California, USA). The difference between means was considered significant when $P$ value $\leq 0.05$.

\section{Results}

\section{Oxidative stress impaired granulosa cell functions}

Bovine granulosa cells treated with $\mathrm{H}_{2} \mathrm{O}_{2}$ exhibited shrinkage in shape and decreased confluency compared with untreated counterparts (Suppl. Figure 1). Moreover,

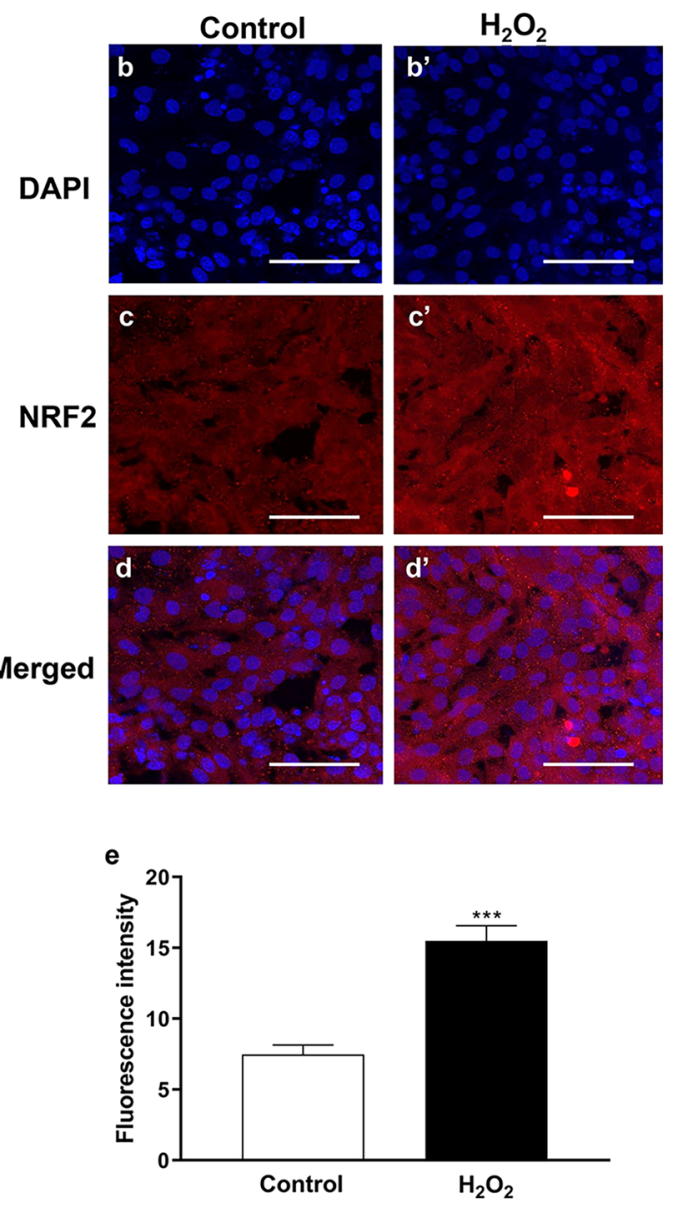

g. The transcript expression data were normalized to internal $A C T B$ and $G A P D H$ as well as relatively compared with the control group. Data were statistically analyzed using Student's two-tailed $t$ test and are represented as means \pm SEM of triplicates $(* p \leq 0.05, * * p \leq 0.01$, $* * * p \leq 0.001)$. The ImageJ software was utilized to calculate the fluorescence intensity of NRF2 protein. Scale bars: $20 \mu \mathrm{m}$ b-d' 
exposure of cells to $\mathrm{H}_{2} \mathrm{O}_{2}$ elevated $(P \leq 0.01)$ the intracellular ROS amount and decreased $(P \leq 0.001)$ mitochondrial activity compared with the untreated controls (Fig. 1a-f). Moreover, the higher intracellular ROS accumulation in $\mathrm{H}_{2} \mathrm{O}_{2}$-challenged cells was accompanied by the induction of DNA fragmentation (Suppl. Figure 2). Overall, these results indicated that bovine granulosa cells treated with $\mathrm{H}_{2} \mathrm{O}_{2}$ resulted in the induction of oxidative stress phenotypes.

\section{$\mathrm{H}_{2} \mathrm{O}_{2}$-induced oxidative stress coupled with endoplasmic reticulum stress}

The mRNA expression level of glucose-regulated protein $(G r p) 78$ and Grp 94 was significantly $(P \leq 0.01$ and $P \leq 0.05$, respectively) higher in $\mathrm{H}_{2} \mathrm{O}_{2}$-treated cells compared with the controls (Fig. 1g). Furthermore, the protein level of Grp78 was in agreement with the corresponding mRNA expression level (Fig. 1h). However, the expression level of Calpainl did not show any significant differences.

\section{$\mathrm{H}_{2} \mathrm{O}_{2}$-induced oxidative stress altered the expression pattern of candidate TFs}

The temporal expression level of the candidate TFs which have pivotal roles in stress response (NRF2, FOS, and $F O S B$ ), apoptosis, differentiation, and proliferation (KLF4, KLF6, KLF9, and NOTCH1), cell cycle (E2F1 and $E 2 F 4$ ), fatty acids and cholesterol biosynthesis (SREBF1 and SREBF2), and immune response (IRF7) was investigated. Upon oxidative stress induction, the expression pattern of $N R F 2$ was significantly increased $(P \leq 0.01$, Fig. 2a). Similarly, the mRNA transcript level of NOTCH1, FOS, SREBF1, SREBF2, KLF6, KLF9, and $E 2 F 1$ was significantly higher $(P \leq 0.05)$ in the $\mathrm{H}_{2} \mathrm{O}_{2}$-treated group compared with the untreated controls (Fig. 2f). Contrary to this, the expression pattern of $K L F 4$ and IRF7 was significantly lower $(P \leq 0.05)$ in $\mathrm{H}_{2} \mathrm{O}_{2}$-treated granulosa cells compared with the untreated control group (Fig. $2 \mathrm{~g}$ ). However, no significant differences were observed in the expression of $E 2 F 4$ and FOSB (Fig. 2g).
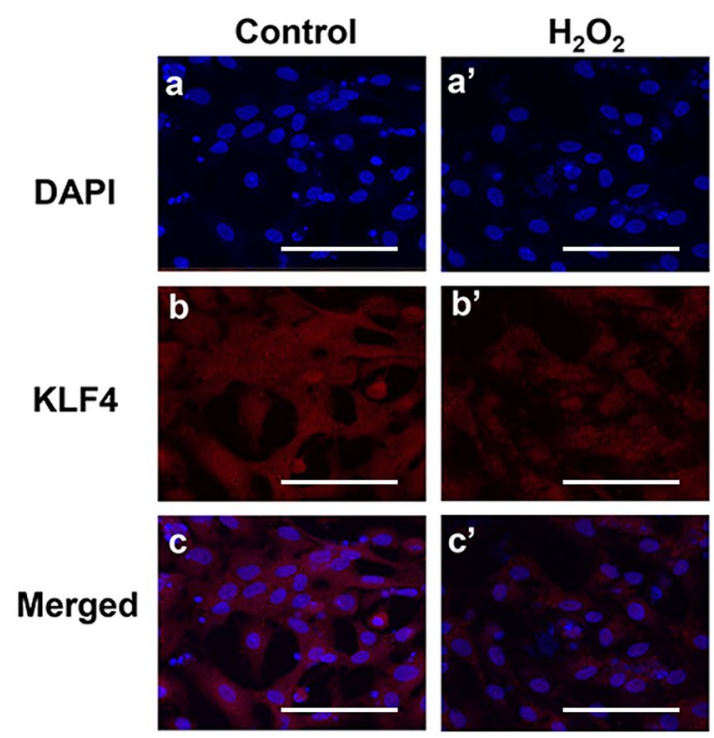

d
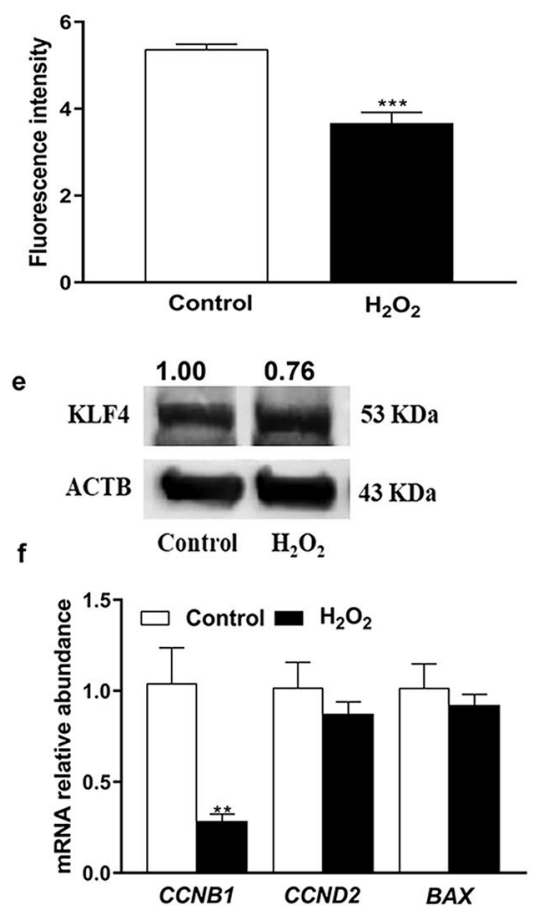

Fig. 3 Impact of oxidative stress on the protein level of KLF4 a-e and its target genes b. The blue color a, a' in immunocytochemistry indicates the nuclear staining using 40,6-diamidino-2-phenylindole (DAPI) and the red color b, b' indicates KLF4 protein. The mRNA data were normalized to $A C T B$ and $G A P D H$ as well as relatively com- pared with the control group. Data represent means \pm SEM from triplicates $(* * p \leq 0.01, * * * p \leq 0.001)$. The Western blot protein analysis of KLF4 e was compared with the internal expression of ACTB. The ImageJ software was utilized to calculate the fluorescence intensity of KLF4 protein. Scale bars: $20 \mu \mathrm{m}$ a-c' 


\section{Oxidative stress influenced the protein level of NRF2 and KLF4}

The protein level of NRF2 and KLF4 was assessed using immunocytochemistry assay after exposure of granulosa cells to oxidative stress. Similar to mRNA expression, the protein abundance of NRF2 was significantly upregulated $(P \leq 0.001)$ in $\mathrm{H}_{2} \mathrm{O}_{2}$-challenged cells compared with controls (Fig. 2c, c', and e). Furthermore, the NRF2 protein was found to be localized in the nucleus of treated cells. However, the protein abundance of KLF4 was significantly lower $(P \leq 0.001)$ in the $\mathrm{H}_{2} \mathrm{O}_{2}$-challenged cells (Fig. 3a-e).

\section{Alterations of downstream genes of KLF4 under oxidative stress condition}

The downregulation of $K L F 4$ in the $\mathrm{H}_{2} \mathrm{O}_{2}$-treated group was accompanied by a significant reduction $(P \leq 0.01)$ of $C C N B 1$ (Fig. 3f). However, the mRNA expression of $C C N D 2$ and $B A X$ was not significantly different between $\mathrm{H}_{2} \mathrm{O}_{2}$-treated and untreated groups (Fig. 3f).

\section{Oxidative stress induced lipid accumulation}

In addition to KLF4, TFs involved in fatty acids and cholesterol biosynthesis (SREBF1 and SREBF2) and cellular lipid accumulation were investigated under oxidative stress condition. Results showed a significant increment $(P \leq 0.05)$ in mRNA expression of PRKAAl (Fig. 4a) as an upstream gene of SREBF1 and $S R E B F 2$. Additionally, the PRKAA1/2 protein level (Fig. 4b) and lipid accumulation (Fig. $4 \mathrm{c}$ and c') were higher in the $\mathrm{H}_{2} \mathrm{O}_{2}$-challenged cells compared with control ones.

\section{Oxidative stress-induced granulosa cell differentiation marker genes}

To clarify whether the exposure of bovine granulosa cells to oxidative stress affected their ability to differentiate, the expression pattern of differentiation marker genes was investigated. The mRNA expression of CYP11Al, $C Y P 19 A 1$, and $S T A R$ was significantly upregulated ( $P \leq 0.001, P \leq 0.01$, and $P \leq 0.01$, respectively) upon exposure of granulosa cells to $\mathrm{H}_{2} \mathrm{O}_{2}$ (Fig. 5a). Additionally, the protein abundance of StAR showed upregulation in challenged cells (Fig. 5b). Moreover, the expression pattern of $E G F R$ was significantly upregulated $(P \leq 0.01)$ in the $\mathrm{H}_{2} \mathrm{O}_{2}$-treated group compared with untreated controls. However, no significant differences were noticed in the mRNA expression level of Inhibin Beta A (INHBa) and Forkhead box $\mathrm{O} 1$ (FOXOl) between the treatment groups (Fig. 5a). a

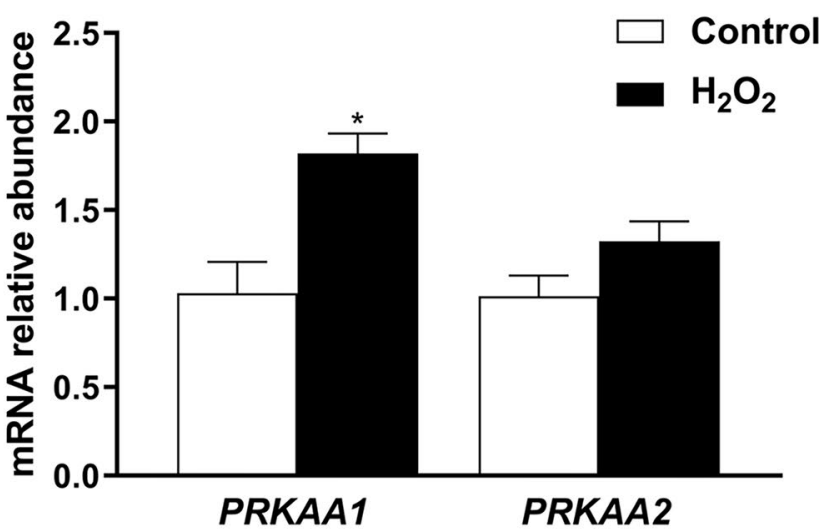

b
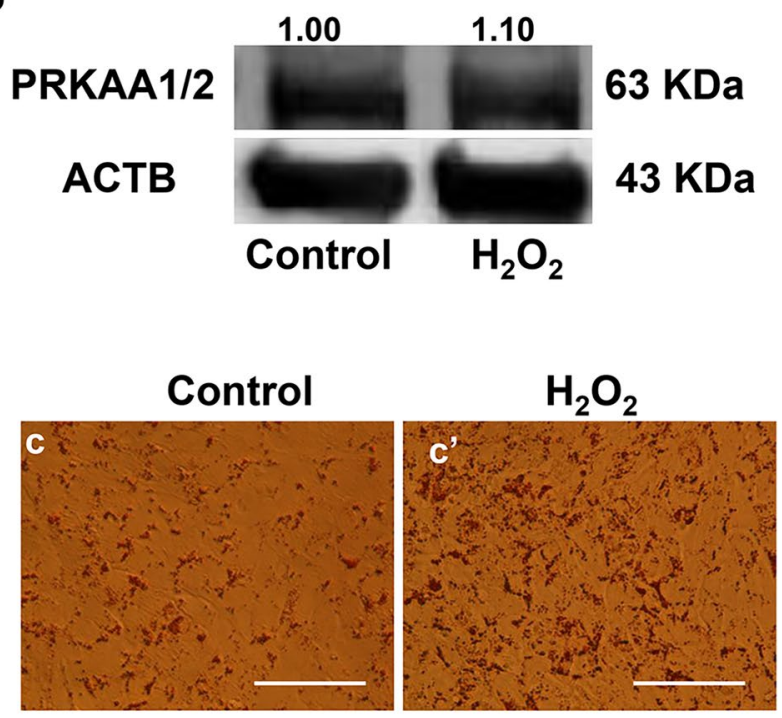

Fig. 4 The effect of oxidative stress on mRNA expression of PRKAA1 and PRKAA2 a, the protein level of PRKAA1/2 b, and lipid accumulation $\mathbf{c}, \mathbf{c}^{\prime}$ in bovine granulosa cells. The red color $\mathbf{c}, \mathbf{c}$ ' indicates the oil red O stain. Data were statistically analyzed using Student's two-tailed $t$ test and represented as means \pm SEM of triplicates $(* p \leq 0.05)$. Scale bars: $25 \mu \mathrm{m}$ c, $\mathbf{c}^{\prime}$

\section{Oxidative stress induced the expression of the pro-apoptotic gene and subsequently impaired granulosa cell proliferation}

Unlike $B A X$, the mRNA level of $C A S P 3$, a pro-apoptotic gene, was significantly increased $(P \leq 0.05)$ in $\mathrm{H}_{2} \mathrm{O}_{2}$-challenged cells (Fig. 5c). However, the expression of the anti-apoptotic marker gene $(B C L 2 L I)$ was significantly decreased $(P \leq 0.05)$ under the $\mathrm{H}_{2} \mathrm{O}_{2}$ challenge. On the other hand, the mRNA and protein expression level of the proliferation marker gene (PCNA) was significantly decreased $(P \leq 0.01)$ under oxidative stress condition (Fig. $5 \mathrm{~d}$ and f). Accordingly, a reduction $(P \leq 0.001)$ in cell proliferation rate was observed upon exposure of granulosa cells to $\mathrm{H}_{2} \mathrm{O}_{2}$ challenge (Fig. 5e). 
a

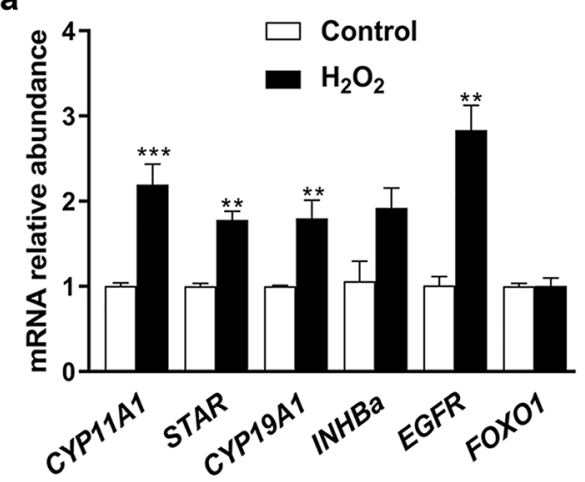

C
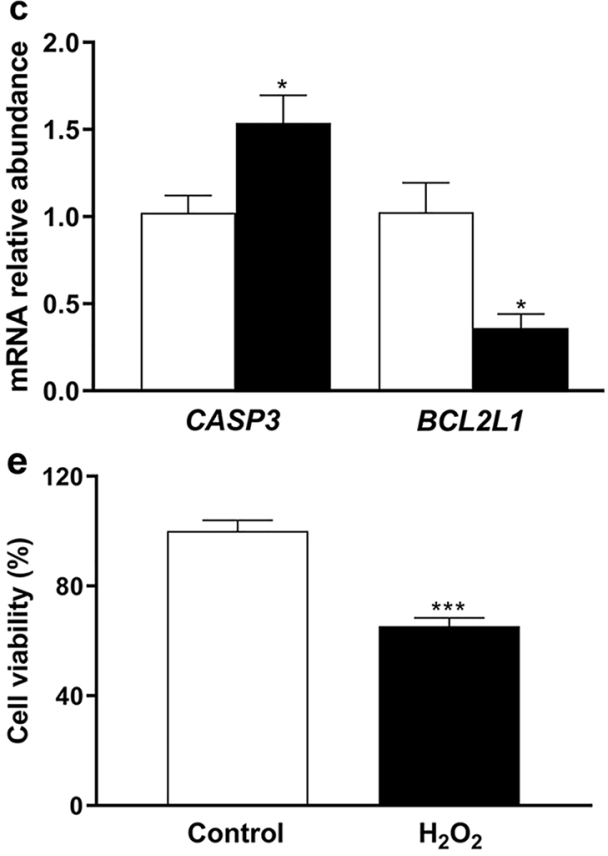

Fig. 5 The mRNA expression pattern of differentiation-related genes (a), StAR protein (b), expression pattern of anti-apoptotic, pro-apoptotic c, proliferation marker $\mathbf{d}$ genes, cell viability $\mathbf{e}$, and PCNA protein level $\mathbf{f}$ in bovine granulosa cells exposed to $\mathrm{H}_{2} \mathrm{O}_{2}$-induced oxidative stress. The geometric mean of $A C T B$ and $G A P D H$ was used for mRNA normalization and the data were relatively compared with the

\section{Selective knockdown of NRF2 altered the expression pattern of stress-related candidate TFs}

The granulosa cells transfected with siRNA targeting $N R F 2$ exhibited reduced expression of NRF2 $(P \leq 0.001$; Fig. 6). Upon $N R F 2$ knockdown, the mRNA expression of KLF9, FOS, NOTCH1, and SREBF2 was significantly downregulated $(P \leq 0.05$; Fig. 6f). Interestingly, the relative mRNA expression of KLF4 was significantly increased $(P \leq 0.001)$ by approximately fivefold. However, the mRNA expression levels of E2F1 and SREBF1 were not significantly altered. b
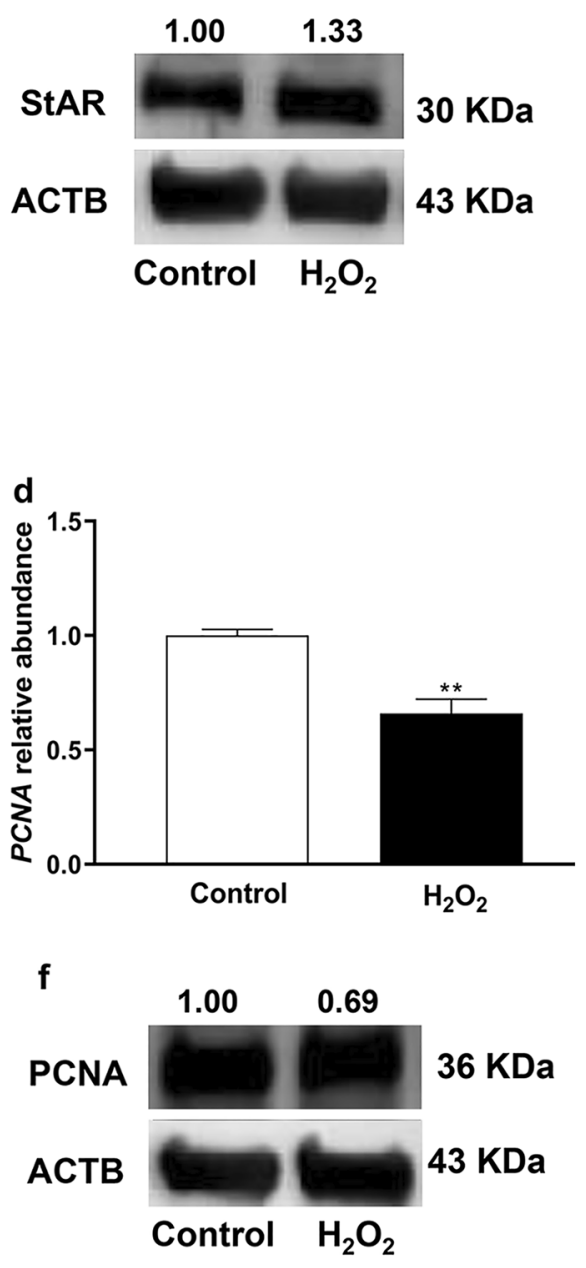

control group. The band intensity of immunoblotting $\mathbf{f}$ was measured by ImageJ software. Data were statistically analyzed with Student's two-tailed $t$ test and are represented as means \pm SEM of triplicates $(* p \leq 0.05, * * p \leq 0.01, * * * p \leq 0.001)$. The level of ACTB protein was used as an internal control in protein analysis

\section{The consequence of NRF2 knockdown on the expression of KLF4 and its downstream genes and cell proliferation}

Targeted suppression of $N R F 2$ resulted in a significant increase in the protein level of KLF4 (Fig. 7a-d). Next, to demonstrate the effect of NRF2 knockdown and induced expression of KLF4 on granulosa cell functions, the expression pattern of KLF4 downstream genes and cell proliferation markers was investigated. Consequently, the mRNA expression of $C C N D 2$ was upregulated $(P \leq 0.05$; Fig. 7e). Intriguingly, the expression pattern of $B A X$ was upregulated $(P \leq 0.01)$ accompanied by a significant reduction $(P \leq 0.01)$ in cell proliferation rate (Fig. 7f). 
a
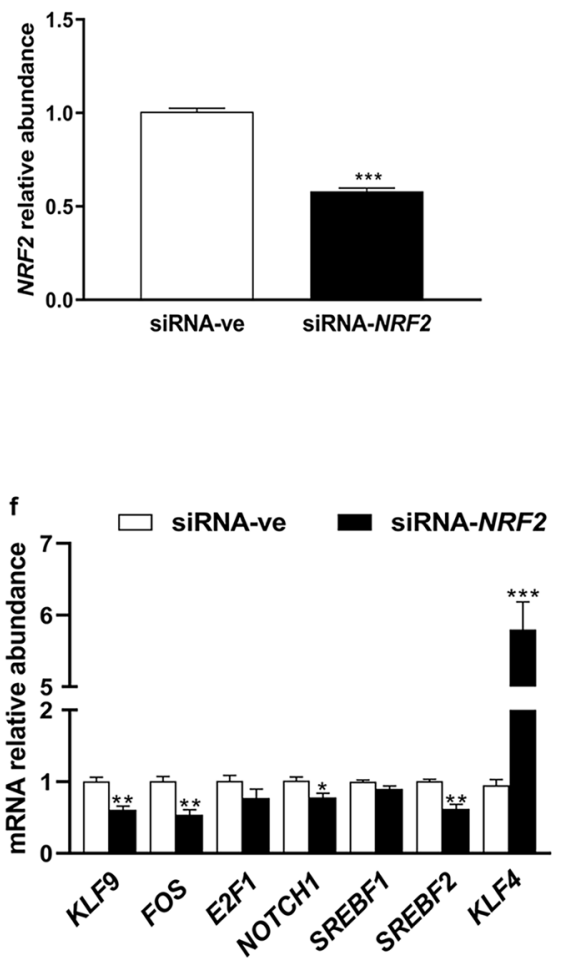

Fig. 6 Selective knockdown of NRF2 in cultured bovine granulosa cells altered the expression of candidate transcription factors; the efficiency of utilizing small interference (siRNA) on the mRNA a and protein b-e levels of $N R F 2$; the impact of siRNA-mediated $N R F 2$ knockdown on the expression pattern of candidate transcription factors $\mathbf{f}$. The mRNA data were normalized to internal control of $A C T B$ and $G A P D H$ as well as the data were relatively compared with the

\section{NRF2 knockdown altered the expression pattern of genes associated with differentiation and lipid accumulation}

The mRNA expression level of the CYP11A1 transcript was significantly reduced $(P \leq 0.05)$ in siRNA-NRF2transfected cells (Fig. 8a) and the mRNA level of INHBa was significantly increased $(P \leq 0.01)$. On the other hand, the NRF2 knockdown resulted in dysregulation of fatty acids and cholesterol biosynthesis TFs, which was confirmed by lower lipid accumulation (Fig. 8 b and b').

\section{Discussion}

In the current study, granulosa cells were exposed to moderate oxidative stress via $5 \mu \mathrm{M} \mathrm{H}_{2} \mathrm{O}_{2}$ treatment as we have used previously (Saeed-Zidane et al. 2017). The $\mathrm{H}_{2} \mathrm{O}_{2}$, one of the non-radical groups of ROS, is diffused through

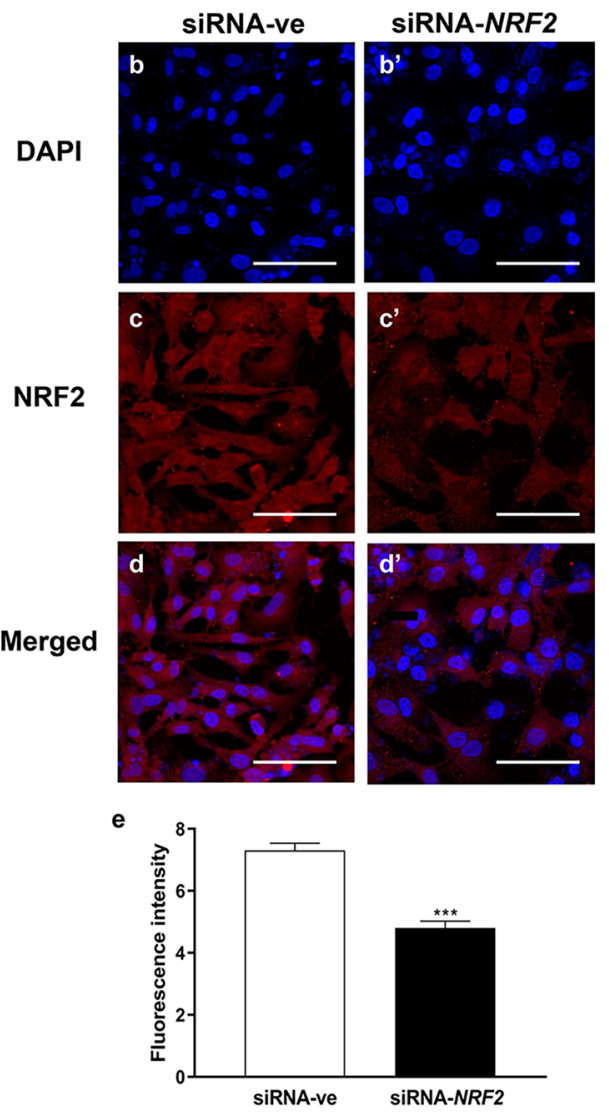

negative control group ( nuclear staining using 40,6-diamidino-2-phenylindole (DAPI) and the red color in immunocytochemistry c, c' indicates NRF2 protein. Data were analyzed with Student's two-tailed $t$ test and are represented as means \pm SEM of triplicates $(* p \leq 0.05$, ** $p \leq 0.01$, ***p $\leq 0.001)$. The ImageJ software was used to measure the fluorescence intensity of NRF2 protein. Scale bars: $20 \mu \mathrm{m}$ b-d'

the cell membrane (Tamma et al. 2018) and subsequently increased the accumulation of intracellular ROS level (Sohel et al. 2019; Zhang et al. 2016). This strategy is orchestrated during the ovulation process by leukocytes, which are deemed to be the source of ROS (Sugino 2005).

Upon increasing intracellular ROS accumulation, the free radicals attack the cellular bioactive molecules such as DNA, lipids, and proteins (Guo et al. 2013; Kadenbach et al. 2004; Zhang et al. 2016), as has been found in the current investigation (Supp. Figure 2). Moreover, the compromising of mitochondrial DNA could cause mutations and subsequently mitochondrial dysfunction (Hollensworth et al. 2000). The permeability of the mitochondrial membrane is prone to lipid peroxidation resulted from the higher levels of ROS, which ultimately impairs the functions of mitochondria and decreases its activity (Guo et al. 2013; Kirkinezos et al. 2005), as shown in the present study (Fig. 1d, d', and f). This could lead to disturbing the cellular metabolism (Kadenbach et al. 


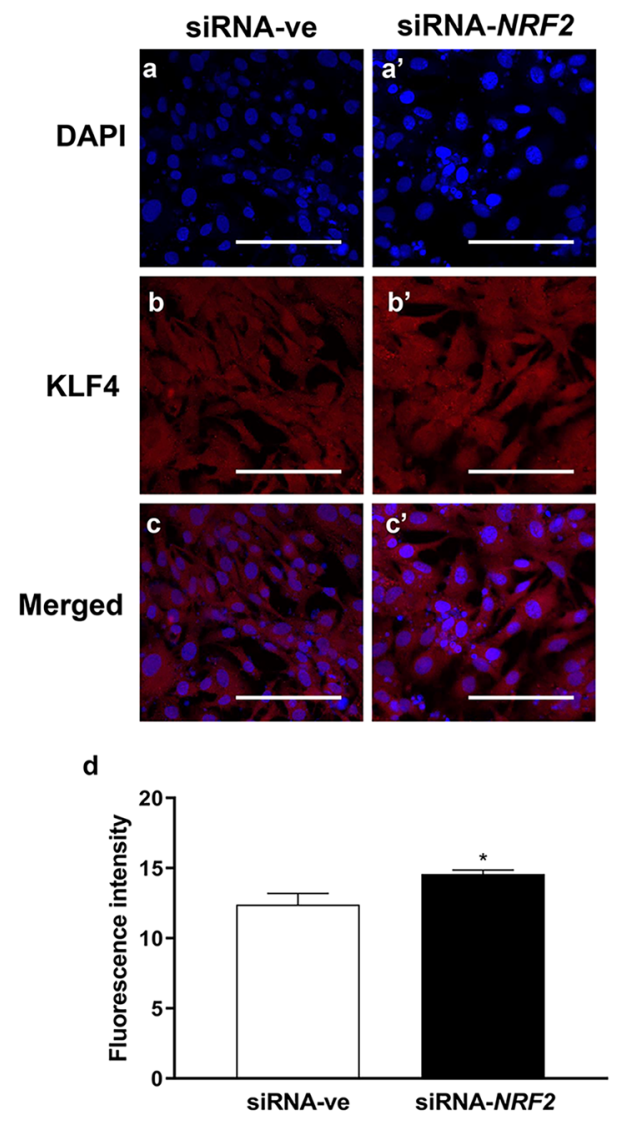

Fig. 7 The effect of transfection with small interference RNA targeting NRF2 (siRNA-NRF2) on the protein level of KLF4 a-d and its target genes $\mathbf{e}$ as well as cell proliferation rate f. The blue color a, a' indicates the nuclear staining using 40,6-diamidino-2-phenylindole (DAPI) and the red color b, b' indicates the KLF4 protein. Data

2004), increase apoptosis (Yang et al. 1997), and decrease cell proliferation as well as alter the cell cycle (Antico Arciuch et al. 2012; Saeed-Zidane et al. 2017). Besides that, $\mathrm{H}_{2} \mathrm{O}_{2}$-induced oxidative stress contributes to altering the protein folding mechanism and induction of endoplasmic reticulum stress (Kim et al. 2016; Malhotra et al. 2008). The endoplasmic reticulum stress has a dual role in ovarian functions either during atresia (Lin et al. 2012) or maturation of the follicle and corpus luteum formation (Huang et al. 2017), which was confirmed in our study by the upregulation of endoplasmic reticulum marker genes (Grp78 and Grp94) mRNA and the protein level of Grp78 (Fig. $1 \mathrm{~g}$ and h). Both Grp78 and Grp94 contribute to the maintenance of endoplasmic reticulum homeostasis and induction of apoptosis via activation of caspase under endoplasmic reticulum stress condition (Liu et al. 2011).

Besides their roles in defense mechanisms in a celldependent manner, several TFs have been proven to play a pivotal role in controlling ovarian functions (Sirotkin 2010). For instance, highly abundant NRF2 protein was
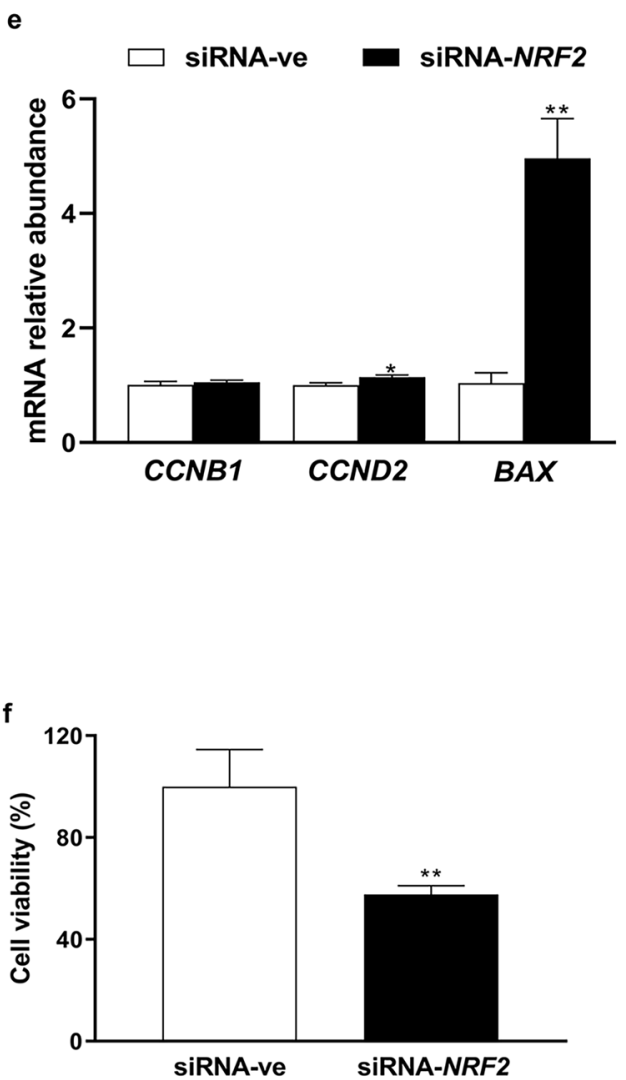

were analyzed with Student's two-tailed $t$ test and are represented as means \pm SEM of triplicates $(* p \leq 0.05, * * p \leq 0.01)$. The ImageJ software was used to measure the fluorescence intensity of KLF4 protein. Scale bars: $20 \mu \mathrm{m}$ a-c'

found to be localized in the porcine follicular cells of the preovulatory follicle and newly formed corpus luteum (Likszo et al. 2019) to trigger the release of antioxidant machinery and subsequently protect the cells from apoptosis (Khadrawy et al. 2019; Likszo et al. 2019; SaeedZidane et al. 2017; Sohel et al. 2019). Similarly, we found upregulation of NRF2 expression in granulosa cells exposed to oxidative stress (Fig. 2), which is the master of TFs involved in oxidative stress response. Furthermore, KLF9-induced apoptosis has been found to be regulated by oxidative stress in cancer cells via NRF2 (Zucker et al. 2014), as has been found in the current study (Fig. 2). Therefore, we speculated the potential role of NRF2 in the regulation of other TFs under oxidative stress conditions and subsequently alteration of ovarian functions.

In ovarian cells, the expression of KLF4 and KLF13 mRNA is regulated by luteinizing hormone $(\mathrm{LH})$ or/and insulinlike growth factor 1 (IGF1) in follicular granulosa cells (Natesampillai et al. 2008), while the dysregulation of $K L F 2$ and KLF4 expression was noticed in polycystic ovary 
a
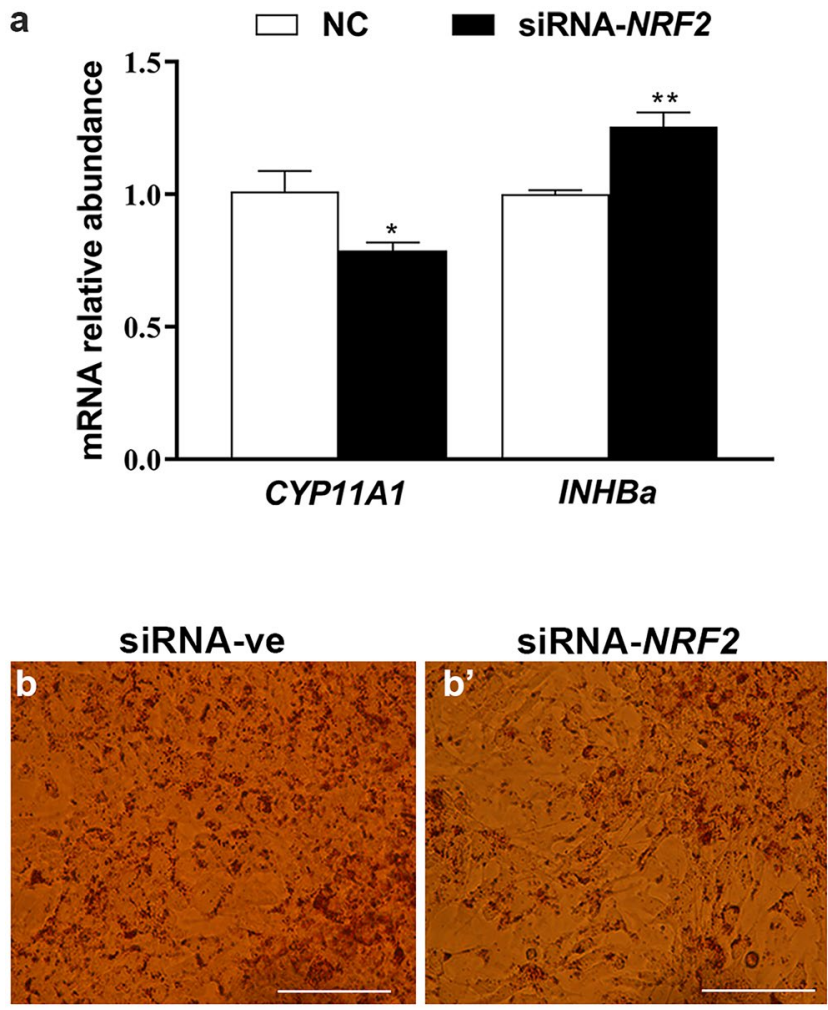

Fig. 8 The effect of siRNA-mediated NRF2 knockdown a and lipid accumulation $\mathbf{b}, \mathbf{b}$ '. The red color $\mathbf{b}, \mathbf{b}$ ' indicates the oil red $\mathrm{O}$ stain. The expression level of $A C T B$ and $G A P D H$ was used to normalize mRNA transcript and the data were relatively compared with the negative control group (siRNA-ve). Data were analyzed with Student's two-tailed $t$ test and represented as means \pm SEM of triplicates $\left({ }^{*} p \leq 0.05,{ }^{* *} p \leq 0.01\right)$. Scale bars: $25 \mu \mathrm{m} \mathrm{b}, \mathbf{b}^{\prime}$

syndrome (PCOS) compared with the normal ovaries (Jansen et al. 2004). In the present study, the mRNA expression of KLF4 was significantly decreased under oxidative stress conditions (Fig. 2g), which was subsequently confirmed by the reduction of its protein level (Fig. 3b, b', and d) and its CCND2 target gene (Fig. 3f). CCND2, which is known to be involved in the regulation of apoptosis ( $\mathrm{Li}$ et al. 2015) and cell cycle (Choi and Roh 2019), is found to be associated with the reduction in cell proliferation rate (Fig. 5e). Furthermore, our previous study showed a reduction in the expression of $C C N D 2$ and subsequently cell cycle arrest at the $\mathrm{G}_{2} / \mathrm{M}$ phase in $\mathrm{H}_{2} \mathrm{O}_{2}$-treated granulosa cells (Saeed-Zidane et al. 2017). The upregulation of KLF4 was found to interfere with the expression of CYP19A1 (Choi et al. 2019), which is responsible for estrogen biosynthesis. However, the reciprocal expression pattern of KLF4 and NRF2 was found during NRF2-knockdown (Fig. 6) resulting in the induction of $B A X$ (Fig. 7e), which is responsible for stimulating the apoptosis in granulosa cells (Yang et al. 2017). This indicates the novel protective role of the NRF2 signaling pathway by inhibiting KLF4-induced apoptosis ( $\mathrm{Li}$ et al. 2015) under oxidative stress conditions.
The reduction of $K L F 4$ expression could be indirectly regulated by the higher expression of $S R E B F 2$, as has been shown in endothelial cells exposed to oxidative stress (Chen et al. 2015). SREBF1 and SREBF2 are TFs involved in the regulation of fatty acids and cholesterol biosynthesis (Shimano 2001). In the preovulatory follicle, the reduction of cholesterol as a consequence of LH-induced steroidogenesis leads to the stimulation of genes coding for cholesterol biosynthesis (Likszo et al. 2019). In agreement with that, our results showed that $S R E B F 1$ and $S R E B F 2$ were found to be upregulated in granulosa cells exposed to oxidative stress conditions (Fig. 2f), which was coupled with a reduction of $K L F 4$ expression and induction of genes responsible for steroidogenic enzymes (Fig. 5). On the other hand, the elevated ROS-induced endoplasmic reticulum stress (Fig. 1) was found to be responsible for increasing the SREBF2-cleavage (Colgan et al. 2007), which is in agreement with our results. Accordingly, the induction of those TFs could lead to increasing lipid accumulation and subsequently promoting of granulosa cell apoptosis and differentiation (Regan et al. 2018), as evidenced by the higher expression of differentiation marker genes (Fig. 5a) and apoptosis (Fig. 5c), as has been previously reported in granulosa cells treated with FSH (Liu et al. 2009). These facts indicate the significant contribution of ROS in granulosa cell transdifferentiation (Shkolnik et al. 2011). Additionally, the dysregulation of $S R E B F$ s' levels resulted in reducing lipid accumulation upon NRF2 knockdown, which indicates the potential role of NRF2 signaling in cellular metabolism through regulation of SREBFs' family (Kamisako et al. 2014). This led to a reduction of $C Y P 11 A 1$ as a differentiation marker gene in granulosa cells (Fig. 8a), which demonstrated the vital role of NRF2 in harmonic with other TFs in the regulation of granulosa cell differentiation.

Moreover, the E2F1, one of E2Fs family involved in cell cycle regulation and apoptosis (Crosby and Almasan 2004), was found to be increased in $\mathrm{H}_{2} \mathrm{O}_{2}$-treated granulosa cells (Fig. 2f). Consistently, the upregulation of $E 2 F 1$ was accompanied by increasing the apoptosis in various cell types (Ginsberg 2002), which is evidenced by increasing DNA fragmentation (Suppl. Figure 2) and decreasing of cell proliferation rate (Fig. 5e) in the present study. Interestingly, as has been evidenced in the current study, there are E2F-binding sites in the NOTCH promotor resulting in the upregulation of NOTCHs' family expression (Viatour et al. 2011).

There is clear evidence that the $\mathrm{NOTCH}$ signaling pathway is implicated in ovarian follicular development, through the spatial and temporal regulation of its associated genes, during follicular growth and selection (Murta et al. 2015; Vanorny et al. 2014; Zhang et al. 2016) as well as corpus luteum steroidogenesis and regression (Murta et al. 2015). Additionally, the stimulation of $N O T C H$ signaling acts as a suppressor of apoptosis signal-regulating kinase 1 (ASKI) 1 and consequently p38 
MAPK signaling pathway (Mo et al. 2013). Accordingly, the upregulation of the NOTCHI transcript in the $\mathrm{H}_{2} \mathrm{O}_{2}$-treated group (Fig. 2f) could be a defense mechanism to suppress the elevation of apoptosis under oxidative stress conditions. This is in agreement with the fact that the NOTCH signaling pathway is involved in the regulation of granulosa cell functions during follicle development (Jing et al. 2017). This novel results in bovine granulosa cells open a new window for further investigations related to TF cross-talk during oxidative stress and their association with apoptosis and differentiation.

Collectively, granulosa cells exposed to oxidative stress showed higher intracellular ROS accumulation accompanied by increased DNA fragmentation and reduced mitochondrial activity. The challenged cells activated the NRF2 signaling pathway in parallel with other TFs involved in apoptosis and differentiation (Suppl. Figure 4), which was remarkably evidenced by the reduction of cell proliferation and induction of steroidogenic genes and lipid accumulation. Those impacts were reversed by $N R F 2$ knockdown. Therefore, the $N R F 2$ signaling pathway in cooperation with other stress-related TFs plays a vital role in the oxidative stress response through regulation of bovine granulosa cells apoptosis and differentiation, which showed its implication for follicular development.

Supplementary Information The online version contains supplementary material available at https://doi.org/10.1007/s00441-021-03445-4.

Author contribution Conceptualization, DT, KS, MH, MOT; methodology, FR, MH, MOT, DSW, CN, MZ; software, DSW, SG.; validation, MOT, SG; formal analysis, DT, SG, ET; investigation, MOT, SG; resources, $\mathrm{MH}, \mathrm{ET}, \mathrm{CN}$; d data curation, MOT, MZ; writing-original draft preparation, MOT; writing-review and editing, MOT, SG, DSW, DT, KS; visualization, MOT; supervision, DT, KS; project administration, DT, KS; funding acquisition, DT, KS.

Funding Open Access funding enabled and organized by Projekt DEAL. Mohamed Omar Taqi was financially supported by the German Academic Exchange Service (DAAD).

\section{Declarations}

Ethical approval This article does not contain any studies with animals performed by any of the authors.

Conflict of interest The authors declare that they have no conflict of interest.

Open Access This article is licensed under a Creative Commons Attribution 4.0 International License, which permits use, sharing, adaptation, distribution and reproduction in any medium or format, as long as you give appropriate credit to the original author(s) and the source, provide a link to the Creative Commons licence, and indicate if changes were made. The images or other third party material in this article are included in the article's Creative Commons licence, unless indicated otherwise in a credit line to the material. If material is not included in the article's Creative Commons licence and your intended use is not permitted by statutory regulation or exceeds the permitted use, you will need to obtain permission directly from the copyright holder. To view a copy of this licence, visit http://creativecommons.org/licenses/by/4.0/.

\section{References}

Agarwal A, Said TM, Bedaiwy MA, Banerjee J, Alvarez JG (2006) Oxidative stress in an assisted reproductive techniques setting. Fertil Steril 86:503-512

Alemu TW, Pandey HO, Salilew Wondim D, Gebremedhn S, Neuhof C, Tholen E, Holker M, Schellander K, Tesfaye D (2018) Oxidative and endoplasmic reticulum stress defense mechanisms of bovine granulosa cells exposed to heat stress. Theriogenology 110:130-141

Amin A, Gad A, Salilew-Wondim D, Prastowo S, Held E, Hoelker M, Rings F, Tholen E, Neuhoff C, Looft C, Schellander K, Tesfaye D (2014) Bovine embryo survival under oxidative-stress conditions is associated with activity of the NRF2-mediated oxidative-stressresponse pathway. Mol Reprod Dev 81:497-513

Andersen CL, Jensen JL, Orntoft TF (2004) Normalization of real-time quantitative reverse transcription-PCR data: a model-based variance estimation approach to identify genes suited for normalization, applied to bladder and colon cancer data sets. Cancer Res 64:5245-5250

Andersson ER, Sandberg R, Lendahl U (2011) Notch signaling: simplicity in design, versatility in function. Development 138:3593-3612

Antico Arciuch VG, Elguero ME, Poderoso JJ, Carreras MC (2012) Mitochondrial regulation of cell cycle and proliferation. Antioxid Redox Signal 16:1150-1180

Chen Z, Wen L, Martin M, Hsu CY, Fang L, Lin FM, Lin TY, Geary MJ, Geary GG, Zhao Y, Johnson DA, Chen JW, Lin SJ, Chien S, Huang HD, Miller YI, Huang PH, Shyy JY (2015) Oxidative stress activates endothelial innate immunity via sterol regulatory element binding protein 2 (SREBP2) transactivation of microRNA-92a. Circulation 131:805-814

Choi H, Roh J (2019) Role of Klf4 in the regulation of apoptosis and cell cycle in rat granulosa cells during the periovulatory period. Int J Mol Sci 20

Choi H, Ryu KY, Roh J (2019) Kruppel-like factor 4 plays a role in the luteal transition in steroidogenesis by downregulating Cyp19A1 expression. Am J Physiol Endocrinol Metab 316:E1071-E1080

Colgan SM, Tang D, Werstuck GH, Austin RC (2007) Endoplasmic reticulum stress causes the activation of sterol regulatory element binding protein-2. Int J Biochem Cell Biol 39:1843-1851

Crosby ME, Almasan A (2004) Opposing roles of E2Fs in cell proliferation and death. Cancer Biol Ther 3:1208-1211

Daemen S, Kutmon M, Evelo CT (2013) A pathway approach to investigate the function and regulation of SREBPs. Genes Nutr 8:289-300

Di Meo S, Reed TT, Venditti P, Victor VM (2016) Role of ROS and RNS sources in physiological and pathological conditions. Oxid Med Cell Longev 2016:1245049

Dias FC, Khan MI, Sirard MA, Adams GP, Singh J (2013) Differential gene expression of granulosa cells after ovarian superstimulation in beef cattle. Reprod 146:181-191

Ginsberg D (2002) E2F1 pathways to apoptosis. FEBS Lett 529:122-125

Guerrero-Netro HM, Chorfi Y, Price CA (2015) Effects of the mycotoxin deoxynivalenol on steroidogenesis and apoptosis in granulosa cells. Reprod 149:555-561

Guo C, Sun L, Chen X, Zhang D (2013) Oxidative stress, mitochondrial damage and neurodegenerative diseases. Neural Regen Res 8:2003-2014 
He L, He T, Farrar S, Ji L, Liu T, Ma X (2017) Antioxidants maintain cellular redox homeostasis by elimination of reactive oxygen species. Cell Physiol Biochem 44:532-553

Hollensworth SB, Shen C, Sim JE, Spitz DR, Wilson GL, LeDoux SP (2000) Glial cell type-specific responses to menadione-induced oxidative stress. Free Radic Biol Med 28:1161-1174

Huang N, Yu Y, Qiao J (2017) Dual role for the unfolded protein response in the ovary: adaption and apoptosis. Protein Cell 8:14-24

Jancar N, Kopitar AN, Ihan A, Virant Klun I, Bokal EV (2007) Effect of apoptosis and reactive oxygen species production in human granulosa cells on oocyte fertilization and blastocyst development. J Assist Reprod Genet 24:91-97

Jang J, Wang Y, Kim HS, Lalli MA, Kosik KS (2014) Nrf2, a regulator of the proteasome, controls self-renewal and pluripotency in human embryonic stem cells. Stem Cells 32:2616-2625

Jansen E, Laven JS, Dommerholt HB, Polman J, van Rijt C, van den Hurk C, Westland J, Mosselman S, Fauser BC (2004) Abnormal gene expression profiles in human ovaries from polycystic ovary syndrome patients. Mol Endocrinol 18:3050-3063

Jing J, Jiang X, Chen J, Yao X, Zhao M, Li P, Pan Y, Ren Y, Liu W, Lyu L (2017) Notch signaling pathway promotes the development of ovine ovarian follicular granulosa cells. Anim Reprod Sci 181:69-78

Kadenbach B, Arnold S, Lee I, Huttemann M (2004) The possible role of cytochrome c oxidase in stress-induced apoptosis and degenerative diseases. Biochim Biophys Acta 1655:400-408

Kamisako T, Tanaka Y, Kishino Y, Ikeda T, Yamamoto K, Masuda S, Ogawa H (2014) Role of Nrf2 in the alteration of cholesterol and bile acid metabolism-related gene expression by dietary cholesterol in high fat-fed mice. J Clin Biochem Nutr 54:90-94

Khadrawy O, Gebremedhn S, Salilew-Wondim D, Taqi MO, Neuhoff C, Tholen E, Hoelker M, Schellander K, Tesfaye D (2019) Endogenous and exogenous modulation of Nrf2 mediated oxidative stress response in bovine granulosa cells: potential implication for ovarian function. Int J Mol Sci 20

Kim JK, Kang KA, Ryu YS, Piao MJ, Han X, Oh MC, Boo SJ, Jeong SU, Jeong YJ, Chae S, Na SY, Hyun JW (2016) Induction of endoplasmic reticulum stress via reactive oxygen species mediated by luteolin in melanoma cells. Anticancer Res 36:2281-2289

Kirkinezos IG, Bacman SR, Hernandez D, Oca-Cossio J, Arias LJ, Perez-Pinzon MA, Bradley WG, Moraes CT (2005) Cytochrome $\mathrm{c}$ association with the inner mitochondrial membrane is impaired in the CNS of G93A-SOD1 mice. J Neurosci 25:164-172

Lai Q, Xiang W, Li Q, Zhang H, Li Y, Zhu G, Xiong C, Jin L (2018) Oxidative stress in granulosa cells contributes to poor oocyte quality and IVF-ET outcomes in women with polycystic ovary syndrome. Front Med 12:518-524

Leite RF, Annes K, Ispada J, de Lima CB, Dos Santos EC, Fontes PK, Nogueira MFG, Milazzotto MP (2017) Oxidative stress alters the profile of transcription factors related to early development on in vitro produced embryos. Oxid Med Cell Longev 2017:1502489

Li W, Jiang Z, Li T, Wei X, Zheng Y, Wu D, Yang L, Chen S, Xu B, Zhong M, Jiang J, Hu Y, Su H, Zhang M, Huang X, Geng S, Weng J, Du X, Liu P, Li Y, Liu H, Yao Y, Li P (2015) Genomewide analyses identify KLF4 as an important negative regulator in T-cell acute lymphoblastic leukemia through directly inhibiting T-cell associated genes. Mol Cancer 14:26

Likszo P, Skarzynski DJ, Moza Jalali B (2019) Proteomic analysis of porcine pre-ovulatory follicle differentiation into corpus luteum. Front Endocrinol (Lausanne) 10:774

Lin P, Yang Y, Li X, Chen F, Cui C, Hu L, Li Q, Liu W, Jin Y (2012) Endoplasmic reticulum stress is involved in granulosa cell apoptosis during follicular atresia in goat ovaries. Mol Reprod Dev 79:423-432
Liu H, Zhang X, Zhang S, Huang H, Wu J, Wang Y, Yuan L, Liu C, Zeng X, Cheng X, Zhuang D, Zhang H (2018) Oxidative stress mediates microcystin-LR-induced endoplasmic reticulum stress and autophagy in KK-1 cells and C57BL/6 mice ovaries. Front Physiol 9:1058

Liu JF, Fong YC, Chang KW, Kuo SC, Chang CS, Tang CH (2011) FPTB, a novel CA-4 derivative, induces cell apoptosis of human chondrosarcoma cells through mitochondrial dysfunction and endoplasmic reticulum stress pathways. J Cell Biochem 112:453-462

Liu Z, Rudd MD, Hernandez-Gonzalez I, Gonzalez-Robayna I, Fan HY, Zeleznik AJ, Richards JS (2009) FSH and FOXO1 regulate genes in the sterol/steroid and lipid biosynthetic pathways in granulosa cells. Mol Endocrinol 23:649-661

Livak KJ, Schmittgen TD (2001) Analysis of relative gene expression data using real-time quantitative PCR and the 2(-Delta Delta C(T)) method. Methods (San Diego, Calif.) 25(4):402-408. https://doi.org/10.1006/meth.2001.1262

Malhotra JD, Miao H, Zhang K, Wolfson A, Pennathur S, Pipe SW, Kaufman RJ (2008) Antioxidants reduce endoplasmic reticulum stress and improve protein secretion. Proc Natl Acad Sci U S A 105:18525-18530

Miao X, Wu X, Shi W (2017) MicroRNA-346 regulates neural stem cell proliferation and differentiation by targeting KLF4. Am J Transl Res 9:5400-5410

Mikaeili S, Rashidi BH, Safa M, Najafi A, Sobhani A, Asadi E, Abbasi M (2016) Altered FoxO3 expression and apoptosis in granulosa cells of women with polycystic ovary syndrome. Arch Gynecol Obstet 294:185-192

Mittal M, Siddiqui MR, Tran K, Reddy SP, Malik AB (2014) Reactive oxygen species in inflammation and tissue injury Antioxid Redox Signal 20:1126-1167

Mo JS, Yoon JH, Ann EJ, Ahn JS, Baek HJ, Lee HJ, Kim SH, Kim YD, Kim MY, Park HS (2013) Notch1 modulates oxidative stress induced cell death through suppression of apoptosis signalregulating kinase 1. Proc Natl Acad Sci U S A 110:6865-6870

Murta D, Batista M, Silva E, Trindade A, Mateus L, Duarte A, Lopesda-Costa L (2015) Differential expression of Notch component and effector genes during ovarian follicle and corpus luteum development during the oestrous cycle. Reprod Fertil Dev 27:1038-1048

Natesampillai S, Kerkvliet J, Leung PC, Veldhuis JD (2008) Regulation of Kruppel-like factor 4, 9, and 13 genes and the steroidogenic genes LDLR, StAR, and CYP11A in ovarian granulosa cells. Am J Physiol Endocrinol Metab 294:E385-391

Rajani S, Chattopadhyay R, Goswami SK, Ghosh S, Sharma S, Chakravarty B (2012) Assessment of oocyte quality in polycystic ovarian syndrome and endometriosis by spindle imaging and reactive oxygen species levels in follicular fluid and its relationship with IVF-ET outcome. J Hum Reprod Sci 5:187-193

Regan SLP, Knight PG, Yovich JL, Leung Y, Arfuso F, Dharmarajan A (2018) Granulosa cell apoptosis in the ovarian follicle-a changing view. Front Endocrinol (Lausanne) 9:61

Saeed-Zidane M, Linden L, Salilew-Wondim D, Held E, Neuhoff C, Tholen E, Hoelker M, Schellander K, Tesfaye D (2017) Cellular and exosome mediated molecular defense mechanism in bovine granulosa cells exposed to oxidative stress. PLoS One 12:e0187569

Shimano H (2001) Sterol regulatory element-binding proteins (SREBPs): transcriptional regulators of lipid synthetic genes. Prog Lipid Res 40:439-452

Shkolnik K, Tadmor A, Ben-Dor S, Nevo N, Galiani D, Dekel N (2011) Reactive oxygen species are indispensable in ovulation. Proc Natl Acad Sci U S A 108:1462-1467 
Sirotkin AV (2010) Transcription factors and ovarian functions. J Cell Physiol 225:20-26

Sohel MMH, Akyuz B, Konca Y, Arslan K, Sariozkan S, Cinar MU (2019) Oxidative stress modulates the expression of apoptosisassociated microRNAs in bovine granulosa cells in vitro. Cell Tissue Res

Sohel MMH, Amin A, Prastowo S, Linares-Otoya L, Hoelker M, Schellander K, Tesfaye D (2018) Sulforaphane protects granulosa cells against oxidative stress via activation of NRF2-ARE pathway. Cell Tissue Res 374:629-641

Sugino N (2005) Reactive oxygen species in ovarian physiology. Reprod Med Biol 4:31-44

Tamma G, Valenti G, Grossini E, Donnini S, Marino A, Marinelli RA, Calamita G (2018) Aquaporin membrane channels in oxidative stress, cell signaling, and aging: recent advances and research trends. Oxid Med Cell Longev 2018:1501847

Tanabe M, Tamura H, Taketani T, Okada M, Lee L, Tamura I, Maekawa R, Asada H, Yamagata Y, Sugino N (2015) Melatonin protects the integrity of granulosa cells by reducing oxidative stress in nuclei, mitochondria, and plasma membranes in mice. J Reprod Dev 61:35-41

Vanorny DA, Prasasya RD, Chalpe AJ, Kilen SM, Mayo KE (2014) Notch signaling regulates ovarian follicle formation and coordinates follicular growth. MolEndocrinol 2014 Apr;28(4):499-511. https://doi.org/10.1210/me.2013-1288. Epub 2014 Feb 19. PMID: 24552588; PMCID: PMC3968400

Viatour P, Ehmer U, Saddic LA, Dorrell C, Andersen JB, Lin C, Zmoos AF, Mazur PK, Schaffer BE, Ostermeier A, Vogel H, Sylvester KG, Thorgeirsson SS, Grompe M, Sage J (2011) Notch signaling inhibits hepatocellular carcinoma following inactivation of the RB pathway. J Exp Med 208:1963-1976
Wen X, Li D, Tozer AJ, Docherty SM, Iles RK (2010) Estradiol, progesterone, testosterone profiles in human follicular fluid and cultured granulosa cells from luteinized pre-ovulatory follicles. Reprod Biol Endocrinol 8:117

Weng Q, Liu Z, Li B, Liu K, Wu W, Liu H (2016) Oxidative stress induces mouse follicular granulosa cells apoptosis via JNK/FoxO1 pathway. PLoS One 11:e0167869

Yang H, Xie Y, Yang D, Ren D (2017) Oxidative stress-induced apoptosis in granulosa cells involves JNK, p53 and Puma. Oncotarget $8: 25310-25322$

Yang J, Liu X, Bhalla K, Kim CN, Ibrado AM, Cai J, Peng TI, Jones DP, Wang X (1997) Prevention of apoptosis by Bcl-2: release of cytochrome c from mitochondria blocked. Sci 275:1129-1132

Zhang JQ, Gao BW, Wang J, Ren QL, Chen JF, Ma Q, Zhang ZJ, Xing BS (2016) Critical role of FoxO1 in granulosa cell apoptosis caused by oxidative stress and protective effects of grape seed procyanidin B2. Oxid Med Cell Longev 2016:6147345

Zhao Q, Mao A, Yan J, Sun C, Di C, Zhou X, Li H, Guo R, Zhang $\mathrm{H}$ (2016) Downregulation of Nrf2 promotes radiation-induced apoptosis through Nrf2 mediated Notch signaling in non-small cell lung cancer cells. Int J Oncol 48:765-773

Zucker SN, Fink EE, Bagati A, Mannava S, Bianchi-Smiraglia A, Bogner PN, Wawrzyniak JA, Foley C, Leonova KI, Grimm MJ, Moparthy K, Ionov Y, Wang J, Liu S, Sexton S, Kandel ES, Bakin AV, Zhang Y, Kaminski N, Segal BH, Nikiforov MA (2014) Nrf2 amplifies oxidative stress via induction of Klf9. Mol Cell 53:916-928

Publisher's Note Springer Nature remains neutral with regard to jurisdictional claims in published maps and institutional affiliations. 